\title{
Genetic analysis confirms the freshwater origin of the endemic Caspian sponges (Demospongiae, Spongillida, Metschnikowiidae)
}

\author{
Agniya M. Sokolova ${ }^{1,2}$, Dmitry M. Palatov ${ }^{2,3}$, Valeria B. Itskovich ${ }^{4}$ \\ I N. K. Koltzov Institute of Developmental Biology, Russian Academy of Science, Vavilova str., 26, Moscow, \\ 119334, Russia 2 A. N. Severtsov Institute of Ecology and Evolution, Russian Academy of Science, Leninskij \\ prosp. 33, Moscow, 119071, Russia 3 Biological faculty, Moscow State University, Leninskie Gory 1 / 12, \\ Moscow, 119991, Russia 4 Limnological Institute of Siberian Branch of Russian Academy of Science, Ulan- \\ Batorskaya, 3, Irkutsk, 664033, Russia \\ Corresponding author: Agniya M. Sokolova (enfado@ya.ru)
}

Academic editor: Pavel Stoev | Received 20 October 2019 | Accepted 20 January 2020 | Published 24 February 2020

http://zoobank.org/5F0413AC-A647-4D27-A91F-5A2A5618A51D

Citation: Sokolova AM, Palatov DM, Itskovich VB (2020) Genetic analysis confirms the freshwater origin of the endemic Caspian sponges (Demospongiae, Spongillida, Metschnikowiidae). ZooKeys 915: 1-16. https://doi. org/10.3897/zookeys.915.47460

\begin{abstract}
The Caspian Sea is a unique inland brackish waterbody inhabited by highly endemic fauna. This fauna consists of species of both marine and freshwater origin. Some Caspian invertebrates cannot be confidently referred to as animals of either origin. The endemic monophyletic family of sponges, Metschnikowiidae, is among them. Although these sponges are considered as fresh water in the modern literature, no researcher has seen them alive for many years, and its status is actually unconfirmed. Here, we present the first photos of Metschnikowia tuberculata Grimm, 1877 and report evidence for its freshwater origin based on analysis of ITS1 and ITS2 sequences and partial sequences of CO1 gene. According to the genetic analysis, M. tuberculata belongs to the order Spongillida. We observed specimens of diverse appearance, but their spicule complement proved to be similar, and ITS sequences were identical. Thus, we conclude that they belong to the same species. The obtained results expand our knowledge about the dispersal ability of freshwater sponges.
\end{abstract}

\section{Keywords}

Caspian Sea, CO1, ITS1, ITS2, Metschnikowia, Porifera, Spongillida

Copyright Agniya M. Sokolova et al. This is an open access article distributed under the terms of the Creative Commons Attribution License (CC BY 4.0), which permits unrestricted use, distribution, and reproduction in any medium, provided the original author and source are credited. 


\section{Introduction}

The Caspian Sea is the largest enclosed inland waterbody on our planet, variously classed as the world's largest lake or a full-fledged sea. Being the residue of ancient seas, the Caspian Sea is completely isolated from oceans now. It is a nondrainage brackish waterbody with profound seasonal and multiannual level oscillations (Kostianoy and Kosarev 2005; Chen et al. 2017). Because of several transgressions and regressions, the history of the Caspian biota is dynamic: periods of faunal isolations and species extinctions alternated with species invasions (Grigorovich et al. 2003). The present fauna comprises nearly $46 \%$ of Caspian endemics and 20\% endemics of the Ponto-Caspian region (Zenkevich 1963). In recent years, the invasion of a few species decreased the endemism percentage, but it is obviously still significant. The Caspian endemics fall into four groups: (1) species of Tethyan origin (e.g., sturgeons, gobiids and clupeids); (2) species originating from brackish Sarmatian or Pontic Lakes, (e.g., the onychopod Cladocera); (3) opportunistic freshwater species (most Rotifera, the non-onychopod Cladocera, most cyprinid fish); (4) a few invaders of northern (Baltic and White Seas) origin, that show few signs of speciation (copepods Limnocalanus grimaldii (Guerne, 1886), several mysids, the Caspian salmon, the Caspian seal) (Dumont 1998). These endemic animals together with freshwater species and species of Atlantic-Mediterranean and Arctic origin represent the current biodiversity of the Caspian Sea (Grigorovich et al. 2003).

In the last century, the Caspian Sea was actively studied, but after the disintegration of the USSR, most of the research ceased. However, some of the Caspian species did not get due consideration even in favorable times. This particularly applies to sponges (phylum Porifera). The endemic Caspian sponges were first described by Grimm in the $19^{\text {th }}$ century (Grimm 1876, 1877). He reported four species: Reniera flava Grimm, 1876, Amorphina caspia Grimm, 1877, Metschnikowia tuberculata Grimm, 1877 and M. intermedia Grimm, 1877. Later, Chernjavsky (1880) described a fifth species, Amorphina protochalina Czerniavsky, 1880, based on a collection of Ulskiy (expedition of Ivashincev, 1856-1867). Then Dybowsky (1880) proposed to synonymize R. flava and Metschnikowia flava and detailed descriptions of the three Metschnikowia species based on, apparently, Grimm's material. After more than 80 years, Koltun (1962) reviewed Grimm's collection and joined $R$. flava, M. tuberculata and M. intermedia into the only one species, Metschnikowia tuberculata, although he did not find the original holotypes. As for Amorphina species, Koltun succeeded in finding the holotype of $A$. protochalina and suggested it to be an aberrant form of $M$. tuberculata. The only found fragment of $A$. caspia was regarded by him as not fitting the original description. Thus, the two Amorphina species were claimed as doubtful and requiring confirmation. In a later comprehensive taxonomic revision of sponges, the Caspian sponges became considered as an endemic family with only one species Metschnikowia tuberculata (Manconi and Pronzato 2002).

The authors concerned with Metschnikowia surmised its relation to marine sponges: Grimm (1877) supposed it to be close to Renieridae or Suberitidae, Lundbeck (1902) assigned it to Renierinae, Annandale (1914) suggested its relationship with Reniera. The habitus and spicule shape (acanthoxeas) of Metschnikowia convinced Koltun (1962), after Martinson (1940), to regard it as a transitional form between marine and freshwater 
sponges. Manconi and Pronzato (2002) placed the family Metschnikowiidae within the freshwater sponges, suborder Spongillina (now order Spongillida). Morrow and Cárdenas (2015) proposed metschnikowiids to be reallocated to marine Haplosclerida, based on their brackish habitat and morphological affinities with Janulum, a marine haplosclerid (although Janulum's skeleton comprises acanthostrongyles but not acanthoxeas).

Thus, given the fact that the Caspian fauna includes species of both freshwater and marine origin, the evolutionary history of sponges remained unknown. So did their actual diversity and ecology because it has been a long time since biologists saw them alive. The current study presents the first photos of live Caspian sponges and their spicules, and the genetic analysis revealing their phylogenetic position.

\section{Material and methods}

\section{Sampling procedures}

The material was collected in the vicinity of Aktau town, Kazakhstan $\left(44^{\circ} 04^{\prime} 88^{\prime \prime N}\right.$, $50^{\circ} 86^{\prime} 98^{\prime \prime} \mathrm{E}$ ), in September 2018. Specimens were gathered by SCUBA diving, snorkeling or by turning over littoral stones. Sponges were carefully detached from rocks and lower parts of large stones by forceps or were collected with the substratum (Mytilus aggregations). Specimens were fixed in 96\% ethanol and RNA-later. When possible, sponges were photographed in situ before collection. For comparative purposes, specimens of $M$. tuberculata from museum collections (deposited in the Zoological Institute of the Russian Academy of Science (ZISP) and partly in the Zoological Museum of Moscow University (ZMMU)) were also investigated.

\section{Morphological analyses}

For scanning electron microscopy (SEM), spicules were purified with potassium dichromate solution and mounted on a stub according to the classical method (Manconi and Pronzato 2000). Measurements of length and width of spicules were taken with light microscopy.

\section{Genetic analysis}

Total genomic DNA extraction was performed using the RIBO-sorb RNA/DNA extraction kit (InterLabService, Russia). The $676 \mathrm{bp}$ fragment at the 5' end of the CO1 gene was amplified and sequenced using universal barcoding primers (Folmer et al. 1994). ITSs were used as a main marker with the best resolution since many species of freshwater sponges have the identical COI sequences (Erpenbeck et al. 2011; Itskovich et al. 2013; Carballo et al. 2018). Previously described primers (Itskovich et al. 2017) were used for amplification of ITS1, 5.8S rDNA and ITS2. Polymerase chain reac- 
tion (PCR) amplifications of ITS1 and ITS2 were performed on a DNA Engine Dyad thermal cycler (Bio-Rad, USA) using the $5^{*}$ ScreenMix (Evrogen). The cycle parameters were initial denaturation at $94^{\circ} \mathrm{C}$ for $120 \mathrm{~s}$, followed by 35 cycles of denaturation at $94{ }^{\circ} \mathrm{C}$ for $30 \mathrm{~s}$, annealing at $55^{\circ} \mathrm{C}$ for $30 \mathrm{~s}$ and extension at $72^{\circ} \mathrm{C}$ for $120 \mathrm{~s}$, followed by a final extension of $8 \mathrm{~min}$ at $72{ }^{\circ} \mathrm{C}$. Each PCR product was purified by electrophoresis in $0.8 \%$ agarose gels and eluted by freezing and thawing. Sequencing of both strands of each PCR product was carried out by Syntol (Russia) using a BIG DYE 3.1 terminator mix on an ABI 377 Sequencer. Chromatograms were analyzed using BioEdit 5.09 (Hall 1999). All sequences have been deposited with GenBank (http://www.ncbi.nlm. nih.gov) with the accession numbers MK659927-MK659935 (ITS1 and ITS2) and MN431221-MN431229 (CO1). The assignment of the sequences obtained from Porifera was performed using the BLAST software program (http://www.ncbi.nlm.nih.gov/ blast/). Sequences were initially aligned using ClustalW 1.7 (Thompson et al. 1994) under default parameters including all available sequences of ITS1 and ITS2 of freshwater sponges available from GenBank, with mandatory manual correction. Phylogenetic trees were constructed using the maximum likelihood (ML) method and Bayesian inference (BI), as implemented in MEGA 5 (Tamura et al. 2011) and MrBayes 3.1.2 (Ronquist and Huelsenbeck 2003). Genetic distances in pairwise comparisons between all analyzed sequences were calculated according to Kimura's 2-parameter model. For the ML analysis, the HKY+G (CO1) and $\mathrm{K} 2 \mathrm{P}+\mathrm{G}$ (ITS1 and ITS2) models were best fitting. The robustness of the ML trees was estimated by bootstrap percentages (Felsenstein 1985) using 500 replicates with heuristic search and stepwise addition starting trees.

Bayesian analyses on nucleotide sequences were run with a parallel version of $\mathrm{Mr}$ Bayes 3.1.2 (Ronquist and Huelsenbeck 2003). Each Bayesian analysis comprised at least two simultaneous runs of eight Metropolis-coupled Markov chains at the default temperature $\left(0.2^{\circ} \mathrm{C}\right)$ under the most general model $(\mathrm{GTR}+\mathrm{G}+\mathrm{I})$ because overparameterization does not negatively affect Bayesian analyses (Huelsenbeck and Rannala 2004). Analyses were terminated after the chains converged significantly, indicated by the average standard deviation of split frequencies $<0.01$. The robustness of the Bayesian trees was estimated by posterior probabilities.

Trochospongilla latouchiana Annandale, 1907 (Spongillidae) was used as the outgroup for ITS sequences because early branching of this genus among Spongillida has been shown in previous phylogenetic reconstructions (Addis and Peterson 2005; Itskovich et al. 2008). This is the most distant taxon of sponges whose ITS sequences are able to be aligned with the sequences of metschnikowiids. Vetulina stalactites Schmidt, 1879 was used as the outgroup for the CO1 sequences as closest marine group (Schuster et al. 2018a).

The World Porifera Database (Van Soest et al. 2020) was used for checking statuses of the taxa under discussion.

\section{Results}

Sponges were abundant in the studied depths $(0.5-5 \mathrm{~m})$ but preferred hidden places. A total of 41 sponges were collected; nine of them were sequenced. 


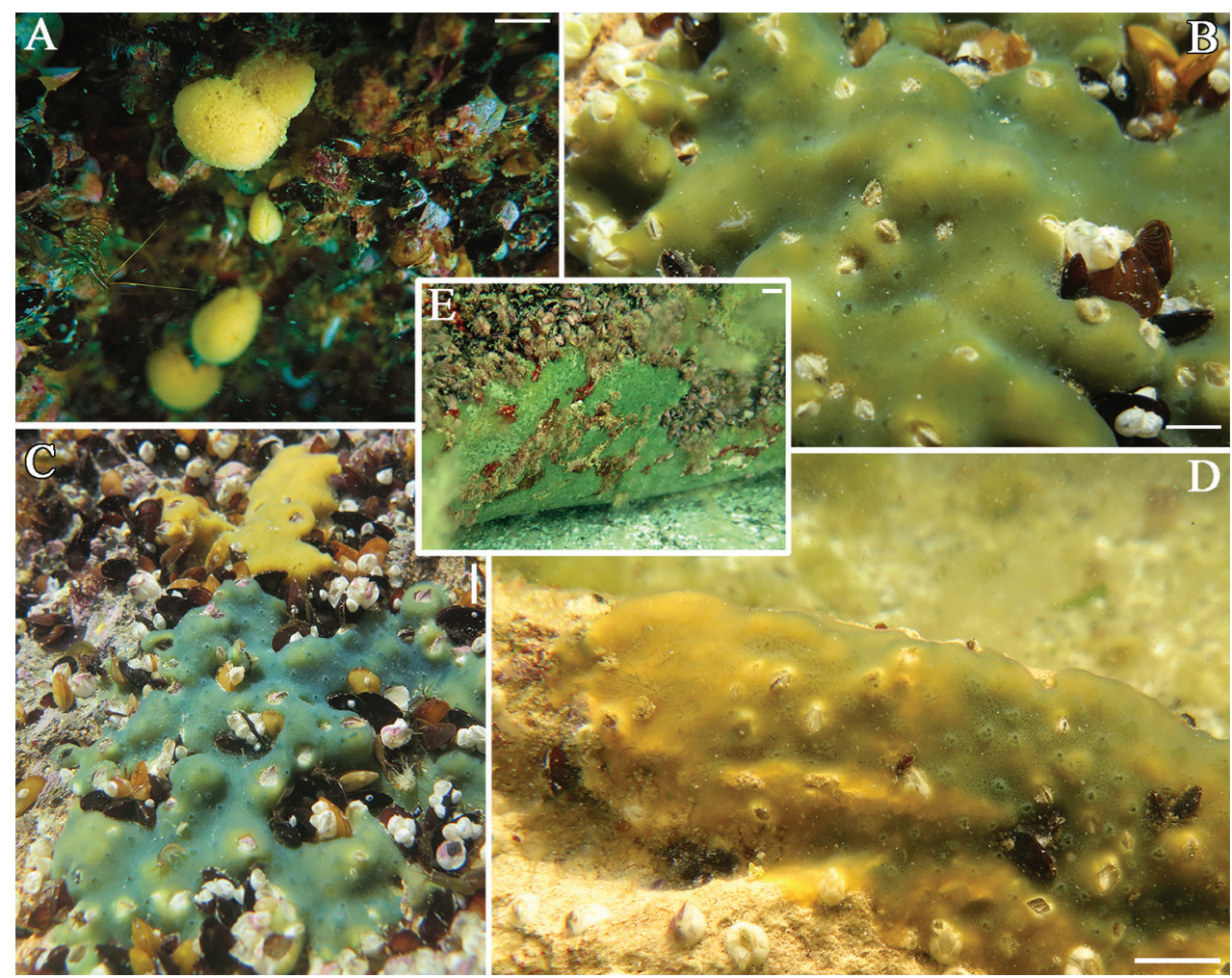

Figure I. In situ photos of Metschnikowia tuberculata. A Globular morph B-E encrusting morphs. Scale bars: $2 \mathrm{~cm}(\mathbf{A}, \mathbf{E}), 1 \mathrm{~cm}(\mathbf{B}, \mathbf{C}, \mathbf{D})$.

\section{General morphology}

We observed sponges of highly variable appearance: crusts of yellow, blue, green or several/ transitional colors and bright-yellow spheres $(\varnothing 2-7 \mathrm{~cm})$ (Fig. 1). Worth noting, the sponges of spherical shape were always of yellow color, while the encrusting shape was not associated with a certain color. Oscula were clearly noticeable, quite regularly arranged, sometimes slightly raised above the surface. In some cases, exhalant canals of star-like structure were seen (Fig. 1 D). One of the encrusting sponge morphs differed from others by having smaller oscula, large body area (up to $70 \mathrm{~cm}^{2}$ ), reduced thickness (3-4 mm) and distinctive faded-green color (Fig. $1 \mathrm{E}$ ).

Thus, two stable morphs could be distinguished among others: thin faded-green encrusting sponges (Fig. 1E) and spherical bright-yellow sponges (Fig. 1A).

\section{Habitat}

The yellow globular morph and faded-green encrusting morph occupied exclusively shaded areas of rocks and lower surfaces of large stones at a depth of $2 \mathrm{~m}$ and more. 
Encrusting sponges of other colors were observed on less-shaded substrata as well as on shaded surfaces at a depth of $50 \mathrm{~cm}$ and more.

\section{Spicule characters}

Spicules were 126-175 $\mu \mathrm{m} \times 3-7.5 \mu \mathrm{m}$ (for more details see Table 1), slightly curved or almost straight oxeas, from finely spiny to greatly spiny (Fig. 2). Sponges of different shapes and colors have no significant distinctions in spicule characters, although oxeas of the yellow globular morphs are generally spinier (Fig. 2D) than in encrusting sponges (Fig. 2A-C). Size and density of spicule spines vary within a specimen.

\section{Skeleton arrangement}

Oxeas constitute paucispicular ascending tracts, sometimes organized in quite regular anisotropic reticulation. The degree of regularity highly varies, and it is more prominent in peripheral parts of sponges. In encrusting forms, tracts protrude outward from the sponge surface (Fig. 2F). In globular sponges we observed a smoother surface with only single spicules piercing the surface layer (Fig. 2E). Spongin is sparse; the basal spongin plate was not found in our material.

\section{Comparison with museum collection}

The only existing museum collection of the Caspian sponges includes spirit specimens (ZISP № 10994-11030, ZMMU № 251-252) and slide preparations. This collection was mainly composed of sponges gathered by Grimm in the $19^{\text {th }}$ century, but now the majority of his material is, apparently, lost. There are also some sporadic specimens from later expeditions. The wholly preserved sponges are often of spherical shape and look identical to the globular yellow sponges collected by us (compare Fig. 1A and Fig. 3A). Their spicule composition has no general differences with spicules of sponges from the Aktau vicinity, but their oxeas have larger spines distributed more densely (Fig. 3B). Spicule size of the museum sponges varies between specimens, but some of them match with our samples (Table 1). Numerous slide preparations (made by V. Koltun in the mid-20 century) allow for the estimation of the diversity of spicule characters. The shape of spicules varied from stout, greatly spiny oxeas to thin, fusiform oxeas that bear minute spines.

\section{Genetic analysis}

COI sequences of nine sponge samples of different colors and shapes were obtained. All sequences (MN431221-MN431229) were identical and have length $676 \mathrm{bp}$. 


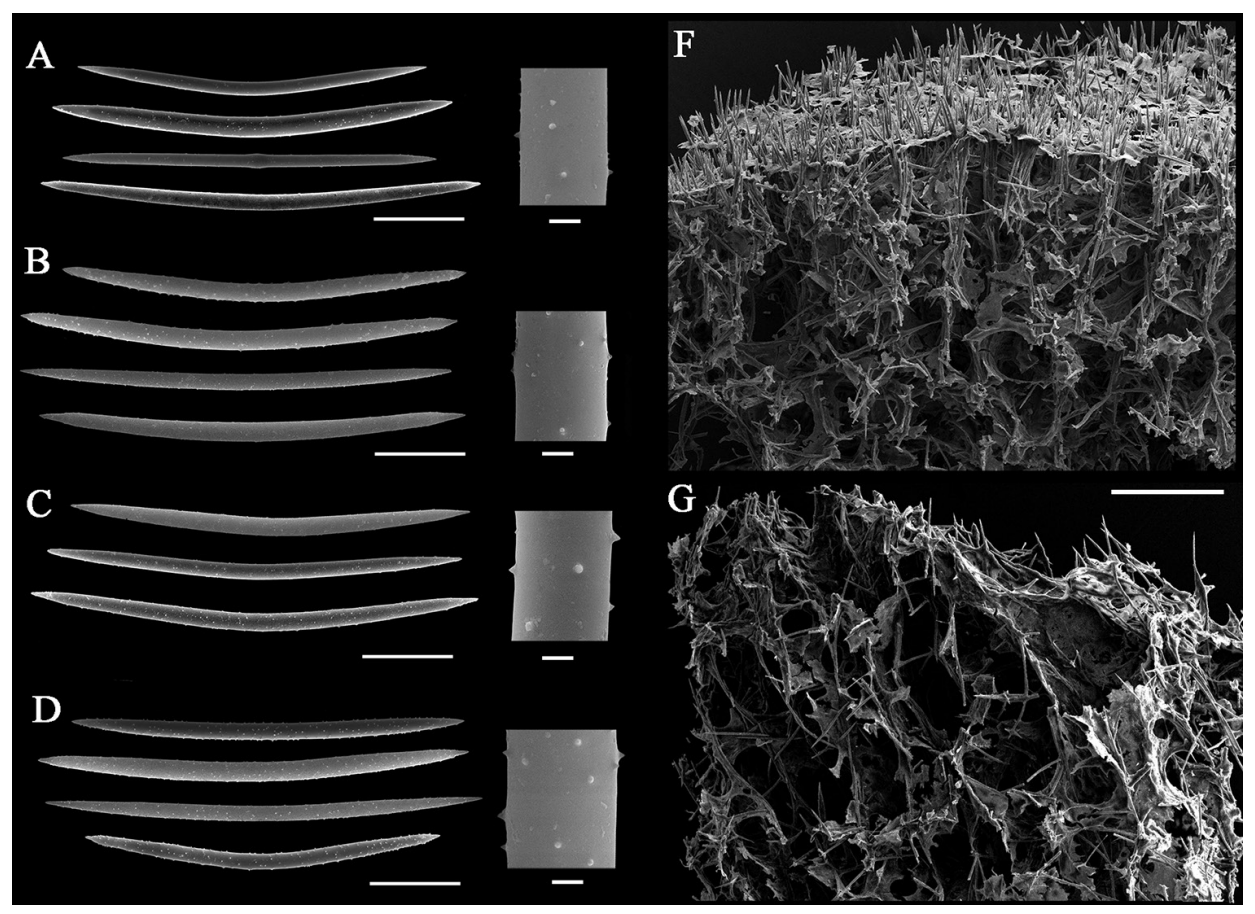

Figure 2. Skeleton complement of Metschnikowia tuberculata. A-C Spicules of encrusting sponges $\mathbf{D}$ spicules of a globular sponge $\mathbf{E}$ skeleton arrangement of a globular sponge $\mathbf{F}$ skeleton arrangement of an encrusting sponge. Scale bars: $30 \mu \mathrm{m}$ (A-D whole spicules); $2 \mu \mathrm{m}$ (A-D magnified parts); $250 \mu \mathrm{m}$ (E, F).

Table I. Measurements of spicules of Metschnikowia tuberculata. YGC - yellow-green crust, YS - yellow sphere, FGC - faded-green crust, BC - blue crust; SD - standard deviation.

\begin{tabular}{|c|c|c|c|c|c|c|c|c|c|}
\hline \multirow[t]{2}{*}{ Specimen } & \multirow[t]{2}{*}{ Appearance } & \multicolumn{4}{|c|}{ Spicule length $(N=25)$} & \multicolumn{4}{|c|}{ Spicule width $(N=25)$} \\
\hline & & $\min$ & mean & SD & $\max$ & $\min$ & mean & SD & $\max$ \\
\hline \multicolumn{10}{|l|}{ Present collection } \\
\hline & YGC & 126.25 & 145.33 & 7.69 & 157.50 & 3.75 & 5.50 & 0.91 & 7.00 \\
\hline & FGC & 125.00 & 152.40 & 10.69 & 175.00 & 4.00 & 5.68 & 0.82 & 7.50 \\
\hline & $\mathrm{BC}$ & 141.25 & 152.50 & 5.33 & 160.00 & 4.75 & 5.82 & 0.82 & 7.25 \\
\hline & YS & 140.00 & 155.14 & 6.73 & 163.75 & 3.00 & 5.03 & 0.72 & 6.50 \\
\hline & YS & 132.50 & 144.20 & 6.57 & 155.00 & 3.75 & 5.60 & 0.92 & 7.25 \\
\hline \multicolumn{10}{|l|}{ Museum collection } \\
\hline $\begin{array}{l}\text { M. t. var. tuberculata ZMMU, } \\
\text { specimen №252 }\end{array}$ & Unknown & 143.00 & 148.42 & 4.46 & 156.00 & 4.00 & 6.50 & 0.99 & 7.90 \\
\hline $\begin{array}{l}\text { M. t. var. tuberculata ZISP, slide } \\
\text { collection, slide №10500 }\end{array}$ & $\begin{array}{l}\text { Presumably YS } \\
\text { (Fig. 3A, upper) }\end{array}$ & 157.50 & 173.26 & 7.91 & 183.25 & 10.25 & 14.00 & 1.38 & 16.25 \\
\hline $\begin{array}{l}\text { M. t. var. intermedia ZISP, slide } \\
\text { collection, slide №10473 }\end{array}$ & Unknown & 117.75 & 148.16 & 11.81 & 165.00 & 4.75 & 5.90 & 0.81 & 7.50 \\
\hline $\begin{array}{l}\text { M. t. var. flava ZISP, slide } \\
\text { collection, slide №10529 }\end{array}$ & Unknown & 151.25 & 172.15 & 10.59 & 192.50 & 7.50 & 12.94 & 1.43 & 15.00 \\
\hline \multicolumn{10}{|c|}{ Museum collection, measurements from Koltun (1962), based on numerous specimens } \\
\hline M. t. var. tuberculata & & 130 & & & 190 & 12 & & & 18 \\
\hline M. t. var. intermedia & & 120 & & & 210 & 8 & & & 19 \\
\hline M. t. var. flava & & 120 & & & 200 & 10 & & & 17 \\
\hline
\end{tabular}




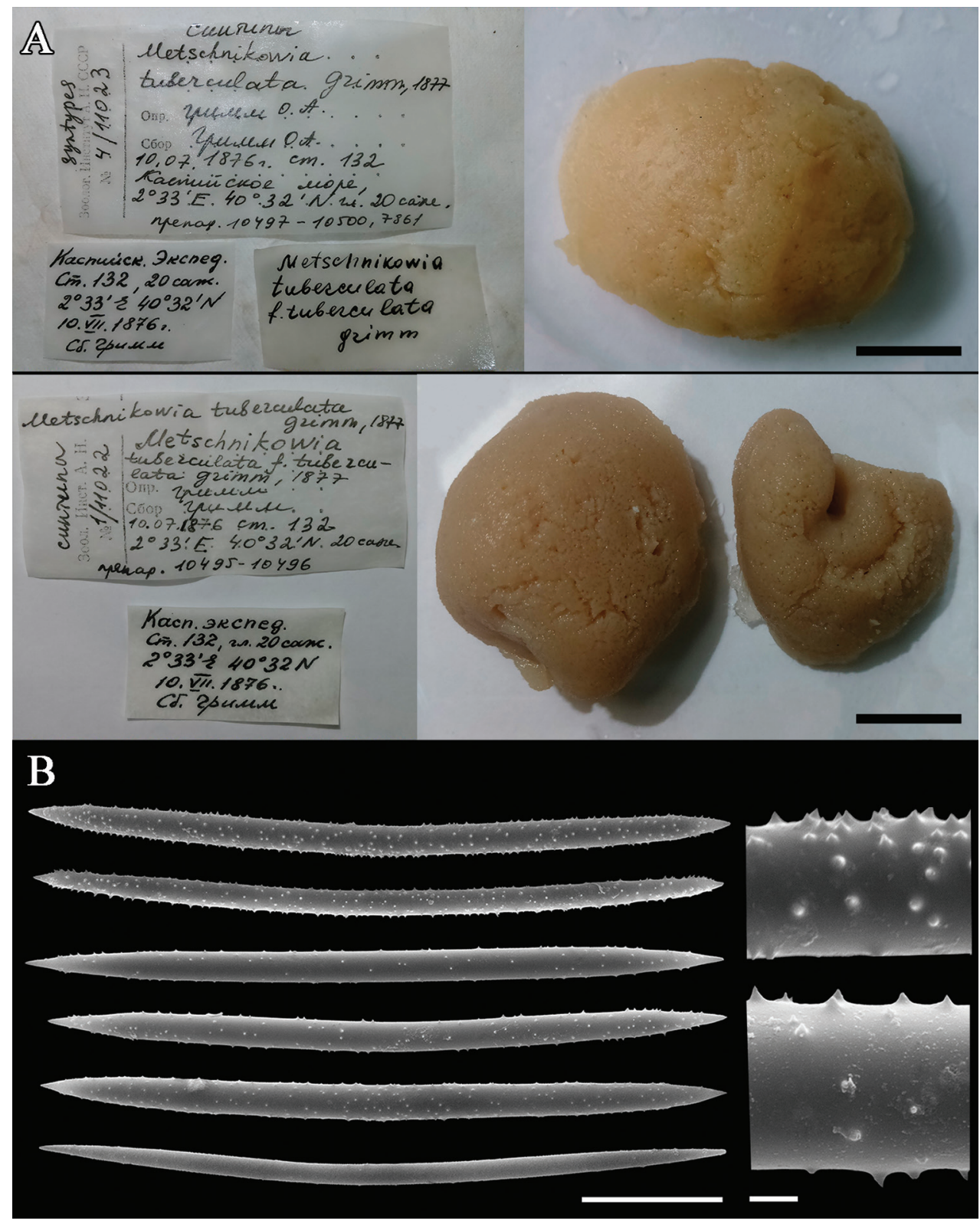

Figure 3. Museum specimens of Metschnikowia tuberculata. A General view of the three syntypes and their labels. Scale bar $1 \mathrm{~cm}$. ZISP, specimen №11023. Collector: Grimm O. A. 10.07.1876, station 132; coordinates $2^{\circ} 33^{\prime} \mathrm{E}, 40^{\circ} 32^{\prime} \mathrm{N}$, depth 20 fathoms (42.6 m). Associated slides: 10497-10500 (upper specimen) and 10495-10496 (lower specimens) B spicular complement of M. tuberculata var. intermedia ZMMU, specimen №251. Scale bars $30 \mu \mathrm{m}$ (whole spicules) and $2 \mu \mathrm{m}$ (magnified part). *The longitude is counted from Baku, i.e., $2^{\circ} 33^{\prime} \mathrm{E}=52^{\circ} 23^{\prime} \mathrm{E}$ 


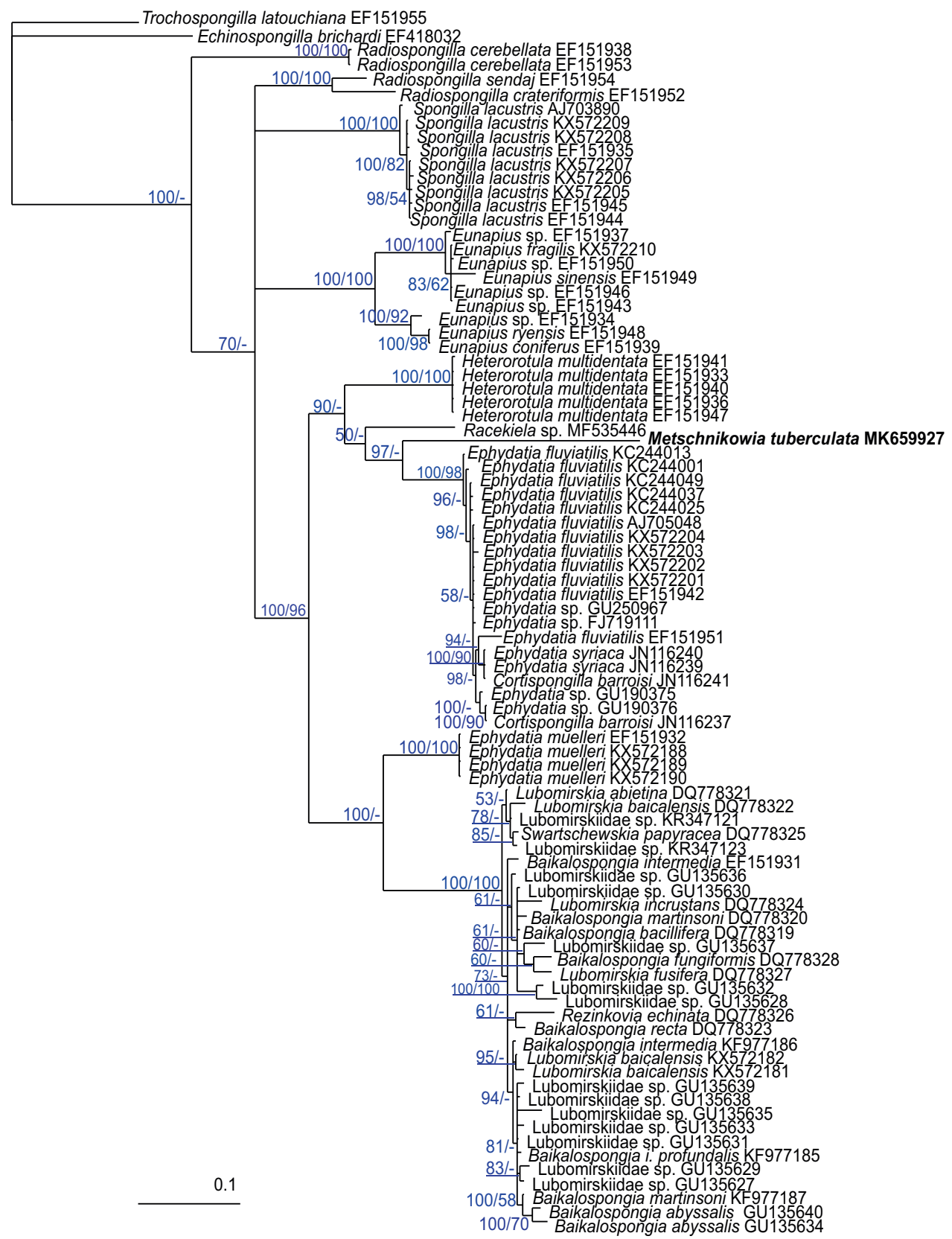

Figure 4. Bayesian phylogenetic tree based on comparisons of 873 bp of ITS 1 and ITS 2 sequences of Spongillida. Nodes are characterized by Bayesian posterior probabilities (\%) followed by bootstrap percentages; a (-) indicates that a particular analysis supported the node at less than $50 \%$, or supported an alternative phylogenetic arrangement in ML tree. Trochospongilla latouchiana (Spongillidae; GenBank EF151955) was used as the outgroup. Scale bar denotes substitutions per site. 
A BLAST analysis revealed that the obtained sequences are most similar to the freshwater sponge Ephydatia fluviatilis (Linnaeus, 1759) (Spongillidae) and differ from its sequence by one nucleotide substitution. The obtained sequences were aligned with available GenBank sequences of Spongillida and Vetulina stalactites (the closest marine relative of Spongillida) and resulted in a 487 bp alignment, in which 28 characters were available for phylogenetic analyses. Phylogenetic reconstructions based on CO1 data obtained with BI and ML had similar topologies with poorly resolved phylogenetic relationships (tree not shown). Mean genetic distance between $M$. tuberculata and other freshwater sponges was $1 \%$ and between $M$. tuberculata and $V$. stalactites was $10 \%$.

ITS1 and ITS2 sequences were obtained from the same specimens. All sequences (MK659927-MK659935) were identical and have length 751 bp. A BLAST analysis revealed that the obtained sequences are most similar to the freshwater sponge Ephydatia fluviatilis (Linnaeus, 1759) (Spongillidae) and other Spongillida. The obtained sequences were aligned with available GenBank sequences of Spongillida and resulted in an 873 bp alignment, in which 437 characters were available for phylogenetic analyses. Marine sponges were not included in the analysis due to the high variability of ITS spacers making the alignment impossible. Phylogenetic reconstructions obtained with BI and ML had generally similar topologies, but the BI-tree shows higher support (Fig. 4).

The analyzed Caspian sponges form a clade with Ephydatia syriaca Topsent, 1910, E. fluviatilis and Cortispongilla barroisi (Topsent, 1892). This clade is included in the common clade with Racekiela sp. and Heterorotula multidentata (Weltner, 1895). All Lubomirskiidae form a strongly supported monophyletic clade with Ephydatia muelleri (Lieberkühn, 1856) as a sister species. Our results also support monophyly of the genus Eunapius. Radiospongilla is paraphyletic to all other species of Spongillidae.

\section{Discussion}

During its existence, the Caspian Sea has repeatedly reconnected with the ocean. Now isolated, this waterbody retains typical marine features, such as characteristic water circulation, the structure of the water mass, hydrochemical properties, production of organic matter in the pelagic zone, geomorphological structure and distribution of organisms. On the other hand, the Caspian water is characterized by lower salt concentration $(12-13 \%$ in the middle and southern parts) and modified salt composition (Karpinsky 2002). Having such a set of features, the Caspian became a cradle of specific fauna, partly of freshwater and partly of marine origin. Some Caspian invertebrates cannot be confidently referred to as animals of either origin, and sponges were among them. The Caspian sponges were known to have typical marine habitus (see pl. I, fig. 1-4 in Koltun 1968), but possess spicules similar to those of freshwater sponges. In addition, their distribution within the sea corresponded rather with the hypothesis of marine origin because sponges were found mainly in the Middle Caspian (Koltun 1962); these waters are much saltier than fresher North Caspian, where sponges were almost absent. Based on skeleton features, the Caspian sponges were considered as a freshwater monotypic 
family Metschnikowiidae (Manconi and Pronzato 2002). Based on genetic data, we have shown that the Caspian sponge Metschnikowia tuberculata indeed has a freshwater origin.

We observed two stable morphs (yellow globules and thin faded-green crusts) and many encrusting sponges with transitional colors. Grimm (1877) also described sponges "of all sorts of shades from pale yellow to bright red" forming "crusts up to $1.5 \mathrm{~cm}$ thick" or having various shapes, "sometimes as large as a child's fist." We find no distinctions between sequences of sponges with different appearances and insufficient dissimilarity of skeleton features. This allows us to consider the morphs as a single species, Metschnikowia tuberculata.

At the same time, we observed some tendency for an increasing number of oxeas' spines in globular sponges compared with encrusting ones. Some encrusting sponges have spicules with minute spines, clearly seen under SEM, but not so obvious under a light microscope. Probably, it was this tendency that led Grimm to misidentify some sponges with smooth spicules as representatives of marine haplosclerid Reniera (accepted name Haliclona) (Grimm 1876). Dybowsky (1880) claimed that Grimm had missed the spines on the spicule surface. Afterward, Koltun (1962) figured out that sponges which had been identified by Grimm as $R$. flava have not only smooth spicules (common of haplosclerids), but also spiny. Moreover, sponges on Grimm's drawing of $R$. flava (Grimm 1876, pl. 3, fig. 1 ) are very similar to those encrusting sponges collected by us due to their distinctive, regularly distributed oscula. Thus, we suggest that Grimm dealt with encrusting Metschnikowia tuberculata having reduced numbers of spines, not with some other sponge.

The Caspian fauna is considered to be in the process of formation because of significant morphological variety of fishes and benthic animals (Ustarbekov 2001), abundance of closely related species with transitional forms, wide ecological niches of species and low specialization and competitiveness compared with saltwater species (in the Black and Azov Seas) (Karpinsky 2002). The first two features are also attributable to sponges of another ancient lake, the Baikal. Being relatively young (Schuster et al. 2018b), its endemic sponges (family Lubomirskiidae) exhibit a large number of transitional morphological forms between species and possess overlapping morphotraits (Itskovich et al. 2015, 2017). Thus, the morphological variety of studied $M$. tuberculata seems not to be surprising.

Comparison of our specimens with the museum collection leaves no doubt that they represent $M$. tuberculata. However, spicules of some sponges from the slide collection stand out from others due to their large size and salient spines. Although freshwater sponges (Spongillida) are known for some spicule variability (e.g., Poirrier 1974, 1976), at present we cannot reveal the limits of variability in Metschnikowia. To determine the true diversity of the Caspian sponges more investigations of specimens from different locations and depths are required.

\section{Phylogeny}

The current study is based on too few specimens and we certainly cannot claim all the Caspian sponges belong to the one species. Nevertheless, our results revealed that 
sponges of different morphs have identical ITS sequences. Taking into account that ITS sequences have a good resolution at species and generic levels in Spongillida (Itskovich et al. 2017), we conclude that all the studied samples belong to the one species, Metschnikowia tuberculata. Genetic distances show that $M$. tuberculata exactly belong to Spongillida.

Our data support the monophyly of freshwater sponges previously predicted by morphological data (Manconi and Pronzato 2002) and confirmed by molecular data (Addis and Peterson 2005; Itskovich et al. 2006; Meixner et al. 2007). Once being descended from marine sponges, Spongillida colonized fresh waters, probably through the coastal brackish waters (Manconi et al. 2013). However, some species remain resistant to slight salinity. For example, Spongilla alba Carter, 1849 is apparently associated with brackish waterbodies (Poirrier et al. 1987; Masuda and Satoh 1990; Gugel 1996). Another instance of salinity tolerance occurs in the widespread sponge Ephydatia fluviatilis, which can survive in mineralized waters like the Baltic Sea (Karlsson et al. 2012) and Lake Issyk-Kul (Weltner 1911).

Thus, the clustering of Metschnikowia with Ephydatia seems not surprising. This clade also supports the hypothesis of the formation of endemic species from cosmopolitan founders (Meixner et al. 2007; Erpenbeck et al. 2011). The high variability of the ITS spacers makes it difficult to align them unambiguously, which leads to low support for deeper nodes (Erpenbeck et al. 2019). Therefore, more markers are required for improving resolution of the trees.

$\mathrm{CO} 1$ of freshwater sponges, conversely, have low variability that resulted in an unresolved phylogeny within Spongillida both in our data and in previous analyses (Meixner et al. 2007; Erpenbeck et al. 2011; Itskovich et al. 2013). Metschnikowia tuberculata possesses new and distinct from E. fluviatilis CO1 haplotype. These data together with ITS data and morphological differences support the separate taxonomic status of the sponges.

Spongillidae is shown to be paraphyletic with respect to the malawispongiid Cortispongilla barroisi, agreeing with the results of Itskovich et al. (2013). Our results support the monophyly of Lubomirskiidae, the sponges of Lake Baikal. They form a strongly supported monophyletic clade with Ephydatia muelleri as a sister species, which is consistent with preceding analyses (Itskovich et al. 2008, 2015; Erpenbeck et al. 2019). However, Radiospongilla turns out to be paraphyletic. Except for this, the obtained results are in accordance with the previous data. They demonstrate the unresolved phylogeny of Spongillida at the family level (Erpenbeck et al. 2011, 2019; Carballo et al. 2018). We believe the revision of the taxonomy of Spongillida at the family level requires the addition of other molecular markers and genomic data.

\section{Acknowledgements}

The work was supported by basic funding № 0345-2019-0002; Russian Foundation for Basic Research (RFBR), project numbers 17-04-01598 (DNA sequencing) and 19- 
34-90084; RFBR and government of the Irkutsk region, project number 17-44-388103 p_a (DNA sequencing). The work of AMS was conducted under the Institute of Developmental Biology National Basic Research Program for 2020 year. Sponge samples were studied using the Joint Usage Center 'Instrumental Methods in Ecology' at A. N. Severtsov Institute of Ecology and Evolution, Russian Academy of Sciences. The research was partially done using equipment of the Core Centrum of Institute of Developmental Biology RAS. The authors are thankful to Nariman Zhaksybekov and Bakhramzhan Novruzov for consulting and providing scuba equipment and Olga Bozhenova (ZISP) for making the photos of the type specimens.

\section{References}

Addis JS, Peterson KJ (2005) Phylogenetic relationships of freshwater sponges (Porifera, Spongillina) inferred from analyses of $18 \mathrm{~S}$ rDNA, COI mtDNA, and ITS2 rDNA sequences. Zoologica Scripta 34: 549-557. https://doi.org/10.1111/j.1463-6409.2005.00211.x

Annandale N (1914) Further Notes on the Sponges of Lake Baikal. Records of the Indian Museum 10: 137-148. https://doi.org/10.5962/bhl.part.5625

Carballo JL, Cruz-Barraza JA, Yáńez B, Gómez P (2018) Taxonomy and molecular systematic position of freshwater genus Racekiela (Porifera: Spongillida) with the description of a newspecies from North-west Mexico. Systematics and Biodiversity 16: 160-170. https:// doi.org/10.1080/14772000.2017.1359216

Chen JL, Wilson CR, Tapley BD, Save H, Cretaux JF (2017) Long-term and seasonal Caspian Sea level change from satellite gravity and altimeter measurements. Journal of Geophysical Research: Solid Earth 122: 2274-2290. https://doi.org/10.1002/2016JB013595

Chernjavsky VI (1880) Shallow water sponges of the Black and Caspian Seas. Bulletin de la Société Impériale des Naturalistes de Moscou 54: 88-128.

Dumont HJ (1998) The Caspian Lake: history, biota, structure, and function. Limnology and Oceanography 43: 44-52. https://doi.org/10.4319/lo.1998.43.1.0044

Dybowsky VI (1880) Studies on sponges of the Russian Empire, with special emphasis on the sponge fauna of Lake Baikal. Mémoires de l'Académie Impériale des sciences de St. Pétersbourg 7: 1-71.

Erpenbeck D, Weier T, de Voogd NJ, Worheide G, Sutcliffe P, Todd JA, Michel E (2011) Insights into the evolution of freshwater sponges (Porifera: Demospongiae: Spongillina): barcoding and phylogenetic data from Lake Tanganyika endemics indicate multiple invasions and unsettle existing taxonomy. Molecular Phylogenetics and Evolution 61: 231-236. https://doi.org/10.1016/j.ympev.2011.05.021

Erpenbeck D, Steiner M, Schuster A, Genner MJ, Manconi R, Pronzato R, Ruthensteiner B, van den Spiegel D, van Soest RWM, Wörheide G (2019) Minimalist barcodes for sponges: a case study classifying African freshwater Spongillida. Genome 62: 1-10. https://doi. org/10.1139/gen-2018-0098

Felsenstein J (1985) Confidence limits on phylogenies: an approach using the bootstrap. Evolution 39: 783-791. https://doi.org/10.1111/j.1558-5646.1985.tb00420.x 
Folmer O, Black M, Hoeh W, Lutz R, Vrijenhoek R (1994) DNA primers for amplification of mitochondrial cytochrome c oxidase subunit I from diverse metazoan invertebrates. Molecular Marine Biology and Biotechnology 3: 294-299.

Grigorovich IA, Therriault TW, MacIsaac HJ (2003) History of aquatic invertebrate invasions in the Caspian Sea. Biological Invasions 5: 103-115. https://doi. org/10.1023/A:1024050824073

Grimm OA (1876) The Caspian Sea and its fauna. Part 1. Trudi Aralo-Kaspiyskoy Expeditsii $1-168$.

Grimm OA (1877) The Caspian Sea and its fauna. Part 2. Trudi Aralo-Kaspiiskoy Expeditsii 1-105. Gugel J (1996) The occurrence of Spongilla alba Carter, 1849 (Porifera, Spongillidae) in Lake Köycegiz (SW Turkey) Zoology in the Middle East 12: 105-108. https://doi.org/10.1080 /09397140.1996.10637696

Hall TA (1999) BioEdit: a user-friendly biological sequence alignment editor and analysis program for Windows 95/98/ NT. Nucleic Acids Symposium Series 41: 95-98.

Huelsenbeck JP, Rannala B (2004) Frequentist properties of bayesian posterior probabilities of phylogenetic trees under simple and complex substitution models. Systematic Biology 53: 904-913. https://doi.org/10.1080/10635150490522629

Itskovich V, Glyzina O, Kaluzhnaya O (2017) Intraspecific and interspecific sequence variability in the ITS region of the rDNA of freshwater sponges of Lake Baikal and East Siberia. Inland Waters 7: 259-266. https://doi.org/10.1080/20442041.2017.1320507

Itskovich V, Gontcharov A, Masuda Y, Nohno T, Belikov S, Efremova S, Meixner M, Janussen D (2008) Ribosomal ITS sequences allow resolution of freshwater sponge phylogeny with alignments guided by secondary structure prediction. Journal of Molecular Evolution 67: 608-620. https://doi.org/10.1007/s00239-008-9158-5

Itskovich V, Kaluzhnaya O, Ostrovsky I, McCormack G (2013) The number of endemic species of freshwater sponges (Malawispongiidae; Spongillina; Porifera) from Lake Kinneret is overestimated. Journal of Zoological Systematics and Evolutionary Research 51: 252-257. https://doi.org/10.1111/jzs.12022

Itskovich V, Kaluzhnaya O, Veynberg E, Erpenbeck D (2015) Endemic Lake Baikal sponges from deep water. 1: Potential cryptic speciation and discovery of living species known only from fossils. Zootaxa 3990: 123-137. https://doi.org/10.11646/zootaxa.3990.1.7

Itskovich VB, Belikov SI, Efremova SM, Masuda Y, Krasko A, Schröder HC, Müller WEG (2006) Monophyletic origin of freshwater sponges in ancient lakes based on partial structures of COXI gene. Hydrobiologia 568: 155-159. https://doi.org/10.1007/s10750-006-0320-z

Karlsson A, Kontula T, Haldin J (2012) Checklist of Baltic Sea Benthic Invertebrate Species. In: Kontula T, Haldin J (Eds) HELCOM Checklist of Baltic Sea Macro-species. Baltic Sea Environment Proceedings 130. Helsinki Commission, Helsinki, 99-195.

Karpinsky MG (2002) Ecology of the benthos of the middle and southern Caspian. Moscow, VNIRO Publishing, 283 pp.

Koltun VM (1962) Sponges of the Caspian Sea. Zoologicheskiy zhurnal 41: 1469-1475.

Koltun VA (1968) In: Birshtein YA, Vinogradov LG, Kondakov NN, Astakhova MS, Romanova NN (Eds) Atlas of Invertebrates of the Caspian Sea. Pishchevaya Promyshlennost, Moscow, 39-40. 
Kostianoy AG, Kosarev AN (2005) The Caspian Sea Environment. The Handbook of Environmental Chemistry. Springer-Verlag, Berlin, Heidelberg, New York, 271 pp. https://doi. org/10.1007/b138238

Lundbeck W (1902) Porifera. Part I. Homorrhaphidae and Heterorrhaphidae. The Danish Ingolf Expedition. V. 6. Bianco Luno, Copenhagen, 1-108.

Manconi R, Pronzato R (2000) Rediscovery of the type material of Spongilla lacustris (L., 1759) in the Linnean herbarium. Italian Journal of Zoology 67: 89-92. https://doi. org/10.1080/11250000009356300

Manconi R, Pronzato R (2002) Suborder Spongillina subord. nov.: freshwater sponges. In: Hooper JNA, Van Soest RWM (Eds) Systema Porifera. A guide to the classification of sponges. Springer, Boston (MA), 921-1020. https://doi.org/10.1007/978-1-4615-0747-5_97

Manconi R, Ruengsawang N, Vannachak V, Hanjavanit C, Sangpradub N, Pronzato R (2013) Biodiversity in South East Asia: an overview of freshwater sponges (Porifera: Demospongiae: Spongillina). Journal of Limnology 72: 313-326. https://doi.org/10.4081/jlimnol.2013.s2.e15

Martinson GG (1940) On investigation of the fossil micro- and spongiofauna of the Baikal region. Trudy Baikalskoy limnologicheskoy stantsii 10: 425-452.

Masuda Y, Satoh K (1990) Freshwater sponges from brackish Lake Shinji and its environs, Japan. Kawasaki Medical Journal, Liberal Arts and Science Course 16: 67-82.

Meixner MJ, Luter C, Eckert C, Itskovich V, Janussen D, von Rintelen T, Bohne AV, Meixner JM, Hess WR (2007) Phylogenetic analysis of freshwater sponges provide evidence for endemism and radiation in ancient lakes. Molecular Phylogenetics and Evolution 45: 875886. https://doi.org/10.1016/j.ympev.2007.09.007

Morrow C, Cárdenas P (2015) Proposal for a revised classification of the Demospongiae (Porifera). Frontiers in Zoology, 12: 7. https://doi.org/10.1186/s12983-015-0099-8

Poirrier MA, Martin PS, Baerwald RJ (1987) Comparative morphology of microsclere structure in Spongilla alba, S. cenota, and S. lacustris (Porifera: Spongillidae). Transactions of the American Microscopical Society 106: 302-310. https://doi.org/10.2307/3226221

Poirrier MA (1974) Ecomorphic variation in gemmoscleres of Ephydatia fluviatilis Linnaeus (Porifera: Spongillidae) with comments upon its systematics and ecology. Hydrobiologia 44: 337-347. https://doi.org/10.1007/BF00036300

Poirrier MA (1976) A taxonomic study of the Spongilla alba, Spongilla cenota, Spongilla wagneri species group (Porifera: Spongillidae) with ecological observations of Spongilla alba. In: Harrison F, Cowden RR (Eds) Aspects of Sponge Biology. New York: Academic Press, 203-213. https://doi.org/10.1016/B978-0-12-327950-7.50019-1

Ronquist F, Huelsenbeck JP (2003) MrBayes 3: Bayesian phylogenetic inference under mixed models. Bioinformatics 19: 1572-1574. https://doi.org/10.1093/bioinformatics/btg180

Schuster A, Pisera A, Kelly M, Bell LJ, Pomponi SA, Wörheide G, Erpenbeck D (2018a) New species and a molecular dating analysis of Vetulina Schmidt, 1879 (Porifera: Demospongiae: Sphaerocladina) reveal an ancient relict fauna with Tethys origin. Zoological Journal of the Linnean Society 184: 585-604. https://doi.org/10.1093/zoolinnean/zlx114

Schuster A, Vargas S, Knapp IS, Pomponi SA, Toonen RJ, Erpenbeck D, Wörheide G (2018b) Divergence times in demosponges (Porifera): first insights from new mitogenomes and 
the inclusion of fossils in a birth-death clock model. BMC evolutionary biology, 18: 114 . https://doi.org/10.1186/s12862-018-1230-1

Tamura K, Peterson D, Peterson N, Stecher G, Nei M, Kumar S (2011) MEGA5: molecular evolutionary genetics analysis using maximum likelihood, evolutionary distance, and maximum parsimony methods. Molecular Biology and Evolution 28: 2731-2739. https:// doi.org/10.1093/molbev/msr121

Thompson JD, Higgins DG, Gibson TJ (1994) CLUSTAL W: improving the sensitivity of progressive multiple sequence alignment through sequence weighting, positions-specific gap penalties and weight matrix choice. Nucleic Acids Research 22: 4673-4680. https:// doi.org/10.1093/nar/22.22.4673

Ustarbekov AK (2001) Morphological variability of the main commercial carp fishes of the Caspian Basin. Proceedings of VIII symposium of Society of Hydrobiology of Russian Academy of Sciences. Vol. 1. Kaliningrad: Kaliningrad State Technical University, 64-75.

Van Soest RWM, Boury-Esnault N, Hooper JNA, Rützler K, de Voogd NJ, Alvarez B, Hajdu E, Pisera AB, Manconi R, Schönberg C, Klautau M, Kelly M, Vacelet J, Dohrmann M, Díaz M-C, Cárdenas P, Carballo JL, Ríos P, Downey R, Morrow CC (2020) World Porifera Database. http://www.marinespecies.org/porifera [Accessed on 2020-01-26]

Weltner W (1911) Spongillidae of the Issyk-Kul Lake and a stream near Jeti-Ögüz. Travaux de la Société Imperiale des Naturalistes de St-Petersbourg 42: 57.

Zenkevich LA (1963) Biology of the Seas of the USSR. USSR Academy of Science, Moscow, $955 \mathrm{pp}$. 